\title{
Regulation of effector function of CNS autoreactive CD4 T cells through inhibitory receptors and IL-7Ra
}

Patrick K Nuro-Gyina', Elizabeth L Rieser ${ }^{2}$, Marissa C Granitto², Wei Pei ${ }^{3}$, Yue Liư ${ }^{4}$, Priscilla W Lee ${ }^{5}$, Saba Aqel ${ }^{3}$, Jian Zhang ${ }^{4}$, Amy E Lovett-Racke ${ }^{4,6}$, Michael K Racke ${ }^{3,6}$ and Yuhong Yang ${ }^{3,7^{*}}$

\begin{abstract}
Background: Multiple sclerosis (MS) is a chronic CNS autoimmune disease characterized by inflammation, demyelination, and neuronal degeneration, where myelin-specific CD4 T cells play critical roles in the formation of acute MS lesions and disease progression. The suppression of IL-7Ra expression and the upregulation of inhibitory receptors (PD-1, etc.) are essential parts of the cell-intrinsic immunosuppressive program regulating $T$ effector functions to prevent autoimmunity. However, little is known on the factors regulating IL-7Ra/PD-1 balance in myelin-specific CD4 T effector/memory cells during the development of CNS autoimmunity.
\end{abstract}

Methods: We analyzed the roles of the transcription factor T-bet in regulating the expression of IL-7Ra and inhibitory receptors in myelin-specific CD4 T cells. Furthermore, we compared the effects of different inflammatory cytokines that are crucial for Th1 and Th17 development in regulating the IL-7Ra/PD-1 balance.

Results: We discovered that T-bet suppresses the expression of inhibitory receptors (PD-1 and LAG-3) and promotes IL-7Ra expression in myelin-specific CD4 T cells in vitro and in vivo. As a result, T-bet skews IL-7Ra/ PD-1 balance towards IL-7Ra and promotes enhanced effector function. Furthermore, IL-12 enhances IL-7Ra expression in a T-bet independent manner in myelin-specific Th1 cells. Meanwhile, IL-6, the cytokine inducing highly encephalitogenic Th17 differentiation, suppresses PD-1 while upregulating IL-7Ra, skewing IL-7Ra/PD-1 balance towards IL-7Ra, and promoting enhanced effector function. Moreover, blocking IL-7 signaling in myelin-specific CD4 T cells by alL-7Ra significantly delays experimental autoimmune encephalomyelitis (EAE) onset and reduces disease severity.

Conclusions: T-bet is a major transcription factor regulating IL-7Ra/PD-1 balance in myelin-specific CD4 T cells during EAE development, and there is a positive correlation between several major determinants promoting $T$ cell encephalitogenicity (T-bet, IL-6, IL-12) and an IL-7Ra/PD-1 balance skewed towards IL-7Ra. Furthermore, IL-7 signaling inhibits PD-1 expression in myelin-specific CD4 T cells and blocking IL-7 signaling suppresses T cell encephalitogenicity. Therefore, interference with inhibitory pathways and IL-7Ra expression may suppress the encephalitogenic potential of myelin-specific CD4 T cells and have therapeutic benefits for MS patients.

Keywords: Multiple sclerosis (MS), Experimental autoimmune encephalomyelitis (EAE), T cell encephalitogenicity, Inhibitory receptors, Transcription factors

\footnotetext{
* Correspondence: yuhong.yang@osumc.edu

${ }^{3}$ Department of Neurology, Wexner Medical Center, The Ohio State University, Columbus, OH, USA

${ }^{7}$ Department of Neurology, Wexner Medical Center, Biomedical Research

Tower, The Ohio State University, 460 W 12th Ave, Room 0604, Columbus,

$\mathrm{OH} 43210$, USA

Full list of author information is available at the end of the article
} 


\section{Background}

Multiple sclerosis (MS) is the leading cause of neurologic disability in the US in young adults after trauma; thus, most patients suffer from the effects of MS for most of their adult life. Experimental autoimmune encephalomyelitis (EAE) is a $\mathrm{T}$ cell mediated autoimmune disease of the central nervous system (CNS), which has served as an animal model for MS for several decades. The formation of acute inflammatory MS lesions is mediated by myelin-specific, autoreactive $\mathrm{T}$ cells [1]. Previous EAE studies have shown that both IFNY producing Th1 cells and IL-17 producing Th17 cells can be highly encephalitogenic effector $\mathrm{T}$ cells, although they have distinct cytokine profiles [2-6]. However, both IFN $\gamma$ and IL-17 deficient mice are still susceptible to EAE induction $[7,8]$, suggesting that molecules other than the signature cytokines may contribute to the regulation of the effector function and encephalitogenicity of myelin-specific Th1 and Th17 cells.

The inhibitory receptors are important immune checkpoints that negatively regulate immune responses to prevent tissue damage and autoimmunity. The roles of inhibitory receptors in the regulation of $\mathrm{T}$ cell effector function have been well-established in $\mathrm{T}$ cell exhaustion, which was identified during chronic viral infection and observed in tumor microenvironment. The axis of PD-1 and its ligand is a central regulator of $\mathrm{T}$ cell exhaustion, although multiple inhibitory receptors, including Lag-3, CTLA-4, Tim3, CD244/2B4, CD160, TIGIT, are involved $[9,10]$. Blockade of the PD-1 pathway partially reversed $\mathrm{T}$ cell exhaustion and reduced viral or tumor load [11-13], which indicated that dysfunctional $\mathrm{T}$ cells could be modulated by manipulating the PD-1 pathway, with implications for the treatment of diseases including chronic infections and cancer. As a result, anti-PD-1 therapy has been developed and shown remarkable success for treating human cancer. Meanwhile, in the context of autoimmunity, recent studies have identified the antagonistic effects of IL$7 R \alpha$ and the inhibitory receptor PD-1 on effector $\mathrm{T}$ cells as essential parts of the cell-intrinsic immunoregulatory program of $\mathrm{T}$ cell effector function. The IL-7R $\alpha$ expression on $\mathrm{T}$ effector/memory cells serves as an on-switch of $\mathrm{T}$ effector cell function, while the expression of the inhibitory receptor PD-1 serves as an off-switch to suppress the effector function of $\mathrm{T}$ cells, which plays an important role in the pathogenesis of autoimmune diabetes [14, 15]. Although both IL-7R $\alpha$ [16-21] and the inhibitory receptor PD-1 [22-24] have been implicated in MS/EAE pathogenesis, it is not clear whether the key cytokines and/or transcription factors that are critical for $\mathrm{T}$ cell encephalitogenicity regulate IL-7R $\alpha / \mathrm{PD}-1$ balance of myelin-specific CD4 T effector/memory cells during
EAE development. Therefore, in this study, we first analyzed the roles of the transcription factor T-bet in the regulation of the expression of IL-7R $\alpha$ and inhibitory receptors in myelin-specific CD4 T cells in vitro and in vivo. Furthermore, we compared the effects of different inflammatory cytokines that are crucial for Th1 and Th17 development in regulating the IL-7R $\alpha / \mathrm{PD}-1$ balance in vitro and in vivo.

\section{Methods}

\section{Animals}

B6/WT and B6/T-bet ${ }^{-/-}$mice were purchased from the Jackson Laboratory and bred in a specific pathogen-free animal facility at the Ohio State University (OSU) Wexner Medical Center. B10.PL mice transgenic for the MBP Ac1-11-specific TCR chains V $\alpha 2.3$ or V $\beta 8.2$ [25] were also bred in a specific pathogen-free animal facility at the OSU Wexner Medical Center. All animal protocols were approved by the OSU Institutional Animal Care and Use Committee.

In vitro culture of splenocytes from TCR transgenic mice Splenocytes were prepared from naive 5-10-week-old $\mathrm{V} \alpha 2.3 / \mathrm{V} \beta 8.2$ TCR transgenic mice and cultured in 24-well plates at $2 \times 10^{6}$ cells/well with irradiated B10.PL splenocytes $\left(6 \times 10^{6}\right.$ cells/well $)$. Cells were activated with MBP Ac1-11 (2 $\mu \mathrm{g} / \mathrm{ml})$ and different combination of cytokines or neutralizing antibodies for cytokines to differentiate effector $\mathrm{T}$ helper cells. Cytokines and antibody concentrations were as follows: $0.5 \mathrm{ng} / \mathrm{ml} \mathrm{IL-12,} 25 \mathrm{ng} / \mathrm{ml}$ IL-6, $1 \mathrm{ng} / \mathrm{ml}$ TGF $\beta 1,2 \mu \mathrm{g} / \mathrm{ml}$ anti-IFN $\gamma, 1 \mu \mathrm{g} / \mathrm{ml}$ anti-IL$12,2 \mu \mathrm{g} / \mathrm{ml}$ anti-IL-4, and $0.35 \mu \mathrm{g} / \mathrm{ml}$ anti-TGF $\beta$ [6].

\section{EAE induction} Immunization

The 8-10-week-old B6/WT, B6/T-bet ${ }^{+/-}$, or B6/T-bet ${ }^{-1-}$ mice were s.c. injected over four sites in the flank with $200 \mu \mathrm{g}$ MOG 35-55 (CSBio Company Inc.) in an emulsion with CFA (Difco); 200 ng pertussis toxin (List) per mouse in PBS was injected i.p. at the time of immunization and $48 \mathrm{~h}$ later.

\section{Adoptive transfer}

Splenocytes were isolated from naïve 5-10-week-old V $\alpha 2.3 / \mathrm{V} \beta 8.2$ TCR transgenic mice and activated with $2 \mu \mathrm{g} / \mathrm{ml}$ of MBP Ac1-11 with or without rmIL-7 $(10 \mathrm{ng} / \mathrm{ml})$ or $\alpha \mathrm{IL}-7 \mathrm{R} \alpha(0.5 \mu \mathrm{g} / \mathrm{ml})$ in 24 -well plates at $2 \times 10^{6}$ cells/well with irradiated B10.PL splenocytes $(6 \times$ $10^{6}$ cells/well). After $72 \mathrm{~h}$, the cells were washed with PBS and $8 \times 10^{6}$ cells/mouse were injected i.p. into naive B10.PL mice.

The mice were evaluated daily for clinical signs of EAE. Mice were scored on scale of 0 to 6: 0 , no clinical disease; 1, limp/flaccid tail; 2, moderate hind limb 
weakness; 3 , severe hind limb weakness; 4, complete hind limb paralysis; 5, quadriplegia or premoribund state; and 6, death.

\section{ELISA}

ELISA was performed to detect the expression of IL-17 and IFN $\gamma$ in supernatant. Purified anti-mouse IL-17 primary antibody (BD Biosciences) was diluted in $0.1 \mathrm{M}$ $\mathrm{NaHCO}_{3}(\mathrm{pH} 8.2)$ at $2 \mu \mathrm{g} / \mathrm{ml}$ while purified anti-mouse IFN $\gamma$ primary antibody was diluted in $0.1 \mathrm{M} \mathrm{NaHCO}_{3}$ ( $\mathrm{pH}$ 9.5) at $2 \mathrm{ug} / \mathrm{ml}$. Immunolon II plates (Dynatech Laboratories) were coated with $50 \mu \mathrm{l}$ of primary antibodies per well and incubated overnight at $4{ }^{\circ} \mathrm{C}$. The plates were washed twice with PBS/0.05\% Tween 20. The plates were blocked with $200 \mu \mathrm{l}$ of $1 \%$ BSA in PBS per well for $2 \mathrm{~h}$. The plates were washed twice with PBS/ $0.05 \%$ Tween 20 , and $100 \mu \mathrm{l}$ of supernatants were added in duplicate. The plates were incubated over-night at $4{ }^{\circ} \mathrm{C}$ and washed four times with PBS/0.05\% Tween 20. Biotinylated rat anti-mouse secondary antibody (BD Biosciences) were diluted in PBS/1\% BSA, $100 \mu \mathrm{lof} 1 \mu \mathrm{g} / \mathrm{ml}$ biotinylated antibody was added to each well, and plates were incubated at room temperature for $1 \mathrm{~h}$. The plates were washed six times with PBS/0.05\%Tween 20, and $100 \mu \mathrm{l}$ avidin-peroxidase was added at $2.5 \mu \mathrm{g} / \mathrm{ml}$ and incubated for $30 \mathrm{~min}$. The plates were washed eight times with PBS/0.05\% Tween 20, and $100 \mu \mathrm{l}$ ABTS substrate containing $0.03 \% \mathrm{H}_{2} \mathrm{O}_{2}$ (for IL-17) or TMB substrate (for IFNY) was added to each well. The plate was monitored for 10-20 min for color development and read at A 405. A standard curve was generated from cytokine standard, and the cytokine concentration in the samples was calculated.

\section{Intracellular staining and flow cytometric analysis}

Flow cytometric analysis was performed to evaluate the expression of surface markers and T-bet in CD4 $\mathrm{T}$ cells, as previously described [6]. Briefly, splenocytes were activated with antigen or $\alpha \mathrm{CD} 3 / \mathrm{CD} 28$ for 48 to $72 \mathrm{~h}$. Cells were then collected, washed, and resuspended in staining buffer (1\% BSA in PBS). The cells were incubated with mAbs to the cell-surface markers for $30 \mathrm{~min}$ at $4{ }^{\circ} \mathrm{C}$. After washing twice with staining buffer, cells were fixed and permeabilized using Cytofix/Cytoperm solution for $20 \mathrm{~min}$ at $4{ }^{\circ} \mathrm{C}$. Cells were stained for intracellular cytokines and T-bet for $30 \mathrm{~min}$ at $4{ }^{\circ} \mathrm{C}$. The 80,000-100,000 live cell events were acquired on a FACSCanto (BD Biosciences) and analyzed using FlowJo software (Tree Star, Inc.). PerCP-anti-CD4 and Pacific Blue-anti-CD44 were purchased from BD Biosciences. PE-anti-PD-1, PE-Cy7-anti-IL-7R $\alpha$, and Pacific Blue-anti-T-bet were purchased from Biolegend Biotechnology, Inc.

\section{Statistical analysis}

GraphPad software (GraphPad Prism Software, Inc., San Diego, CA, USA) was utilized for statistical analysis. A statistically significant difference in EAE clinical scores was considered to be $P<0.05$, as determined by Mann-Whitney U test. The Mann-Whitney $\mathrm{U}$ test is non-parametric, and therefore accounts for the fact that EAE scores are ordinal and not intervalscaled. ELISA and quantitated flow data comparisons were performed using two-tailed unpaired student's $t$ tests. Differences with $P<0.05$ were considered significant.

\section{Results}

T-bet suppresses the expression of inhibitory receptors in myelin-specific CD4 T cells during EAE development

T-bet is a transcription factor that regulates Th1 differentiation and is critical for the encephalitogenicity of Th1 cells and EAE development [26-31]. A previous study in a chronic infection model showed that T-bet represses PD-1 expression on CD8 T cells and sustains viral-specific CD8 $\mathrm{T}$ cell responses [32]. However, it is not clear if T-bet regulates PD-1 expression in myelinspecific CD4 T cells during EAE development. Furthermore, LAG-3, another inhibitory co-receptor, has been shown to act synergistically with PD-1 to prevent autoimmunity. Therefore, we determined the expression of inhibitory receptors (PD-1 and LAG-3) on myelinspecific CD4 T cells when T-bet is deficient. Splenocytes from naïve MBP-specific TCR transgenic mice that were T-bet $^{+/+}$(TCR-WT) or T-bet ${ }^{-/-}$(TCR-T-bet $^{-/-}$) were activated with MBP Ac1-11 for $72 \mathrm{~h}$, followed by resting for 4 days, and reactivation with MBP Ac1-11 for 2 days. At the end of primary stimulation, PD-1 and LAG-3 expressing myelin-specific effector CD4 T cells were significantly higher in $\mathrm{T}^{- \text {bet }^{-/-}}$group compared to WT group (Fig. 1a). Moreover, there were more CD4 T cells co-expressing PD-1 and LAG-3 in T-bet ${ }^{-/-}$group compared to WT group (Fig. 1a). Almost all LAG-3 expressing CD4 $\mathrm{T}$ effector cells express $\mathrm{PD}-1$, suggesting the potentially synergic effects of these inhibitory receptors. After resting for 4 days, PD-1 expressing cells were still significantly higher in $\mathrm{T}^{-b^{-}}{ }^{-/-}$myelin-specific $\mathrm{CD}^{+} \mathrm{CD}_{4} 4^{+} \mathrm{T}$ effector cells (Fig. 1b upper panels), while LAG-3 expression was compatible between two groups (Fig. 1b lower panels). Secondary stimulation with MBP Ac1-11 resulted in significantly higher PD1 expression in $\mathrm{T}^{-\mathrm{bet}^{-/}}$myelin-specific CD4 $\mathrm{T}$ effector cells compared to WT CD4 T effector cells (Fig. 1c), suggesting that $\mathrm{T}$-bet negatively regulates PD-1 expression in myelin-specific effector CD4 T cells.

To further confirm the negative regulation of PD-1 expression by T-bet, we analyzed PD-1 expression in 


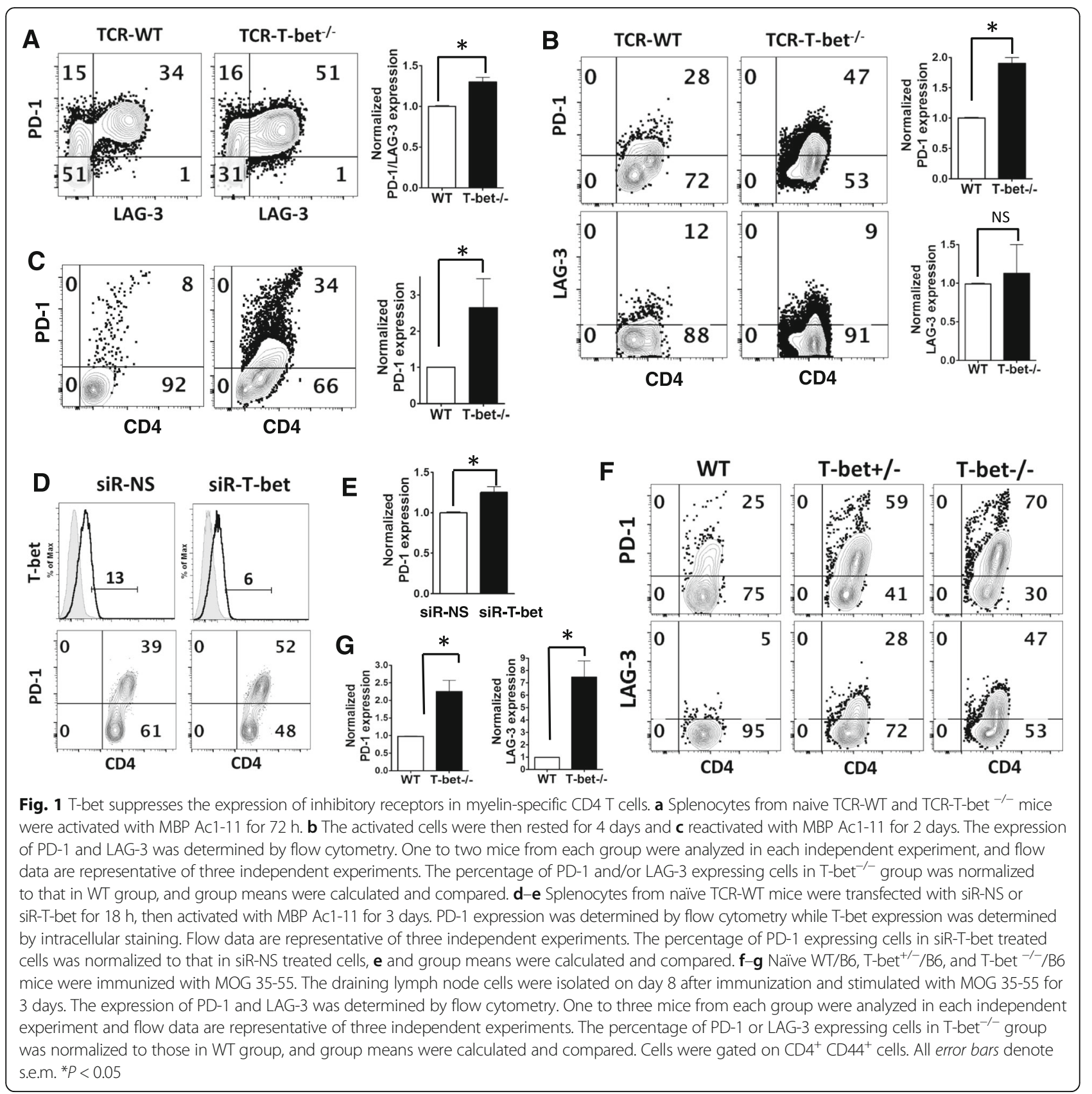

myelin-specific CD4 T cells when T-bet expression was inhibited by a siRNA specific for T-bet $[6,29,33]$. As shown in Fig. 1d-e, suppression of T-bet by siRNA leads to significantly increased expression of PD-1 in myelin-specific CD4 $\mathrm{T}$ cells transfected with T-bet siRNA (siR-T-bet), confirming that T-bet negatively regulates $\mathrm{PD}-1$ expression in myelin-specific CD4 $\mathrm{T}$ cells differentiated in vitro. Next, we determined PD1 expression in T-bet deficient myelin-specific CD4 T cells during EAE development in vivo. Naïve WT/B6, T-bet ${ }^{+/-} / \mathrm{B} 6$, and T-bet ${ }^{-1-} / \mathrm{B} 6$ littermate mice were immunized with MOG 35-55/CFA. The draining lymph node cells were isolated on day 8 after immunization and activated in vitro with MOG 35-55 for 3 days. As shown in Fig. 1f-g, PD-1 expression inversely correlated with T-bet expression (Fig. 1f upper panels), with the highest PD-1 expressing CD4 T cells in the T-bet $^{-/-}$group, which were significantly higher than those in WT group (Fig. 1g). Similar pattern was observed with LAG-3 expression level (Fig. 1f lower panels and g), indicating that T-bet negatively regulates the expression of inhibitory receptors in myelin-specific CD4 T cells during EAE development in vivo. 
T-bet enhances IL-7Ra expression in myelin-specific CD4 T cells

As recent studies have shown that the IL-7R $\alpha / P D-1$ balance is important for the effector function of CD4 $\mathrm{T}$ cells, we determined if T-bet regulates IL-7R $\alpha$ expression. Splenocytes from naïve TCR-WT and TCR-T-bet ${ }^{-1-}$ mice were activated with MBP Ac1-11 for $72 \mathrm{~h}$, followed by 4 days of rest and reactivation with MBP Ac1-11 for 2 days. At the end of primary stimulation, IL-7R $\alpha$ expressing cells were significantly lower in $\mathrm{T}^{-}$bet $^{-/-}$ myelin-specific $\mathrm{CD} 4^{+} \mathrm{CD} 44^{+} \mathrm{T}$ effector cells compared to WT group (Fig. 2a). After 4 days of rest, the T-bet ${ }^{-/-}$ myelin-specific $\mathrm{CD} 4{ }^{+} \mathrm{CD} 44^{+} \mathrm{T}$ effector cells showed increased IL-7R $\alpha$ expression, which is the inverse of the activated $\mathrm{T}$ cells. The IL-7R $\alpha$ expression in $\mathrm{T}$-bet ${ }^{-/-}$ myelin-specific $\mathrm{CD} 4^{+} \mathrm{CD} 44^{+} \mathrm{T}$ effector cells was significantly higher than that in WT $\mathrm{CD} 4^{+} \mathrm{CD} 44^{+} \mathrm{T}$ cells after rest (Fig. 2b), However, after antigen restimulation, T-bet $^{-/-}$myelin-specific CD $4^{+} \mathrm{CD} 44^{+} \mathrm{T}$ effector cells and WT $\mathrm{CD} 4^{+} \mathrm{CD} 44^{+} \mathrm{T}$ effector cells showed comparable IL-7R $\alpha$ expression (Fig. 2c), but T-bet ${ }^{-/-}$myelin-specific CD4 $\mathrm{T}$ effector cells expressed significantly higher PD-1 than WT CD4 T effector cells (Fig. 1c). Together, these data indicate that T-bet is a major transcription factor regulating IL-7R $\alpha / \mathrm{PD}-1$ balance in myelin-specific CD4 T cells in vitro and in vivo. T-bet enhances IL-7R $\alpha$ expression while suppressing the expression of the inhibitory receptors. As a result, T-bet expression leads to enhanced effector function of myelin-specific CD4 $\mathrm{T}$ cells by skewing the IL-7R $\alpha /$ PD-1 balance towards IL-7R $\alpha$. When T-bet is deficient, the expression of inhibitory receptors in myelin-specific CD4 T effector cells is upregulated and IL-7R $\alpha$ expression is downregulated, leading to impaired effector function.

\section{IL-12 promotes IL-7Ra expression in a T-bet independent manner}

As IL-12 plays a critical role in regulating Th1 differentiation and CD4 T effector function, we examined if IL-12 regulates the expression of inhibitory receptors and IL$7 R \alpha$ in myelin-specific Th1 cells and whether the effect is dependent on T-bet. Exogenous IL-12 does not alter the expression of inhibitory receptors (PD-1 or LAG-3) (Fig. 2d-e upper panels) but leads to a significant increase of IL-7R $\alpha$ expressing myelin-specific $\mathrm{CD} 4^{+} \mathrm{CD} 44^{+}$ $\mathrm{T}$ effector cells in both WT group (Fig. 2d lower panels) and $\mathrm{T}^{-}$bet $^{-1-}$ group (Fig. 2e lower panels), suggesting that IL-12 enhances IL-7R $\alpha$ expression in myelinspecific CD4 $\mathrm{T}$ cells in a T-bet independent manner. After antigen restimulation, IL-7R $\alpha$ expression among the cells treated or not treated with IL-12 in primary stimulation is at similar low level compared to primary stimulation (Fig. 2f-g). These data suggest that IL-12 not only regulates IL-7R $\alpha / \mathrm{PD}-1$ balance through inducing T-bet expression but also promotes IL-7R $\alpha$

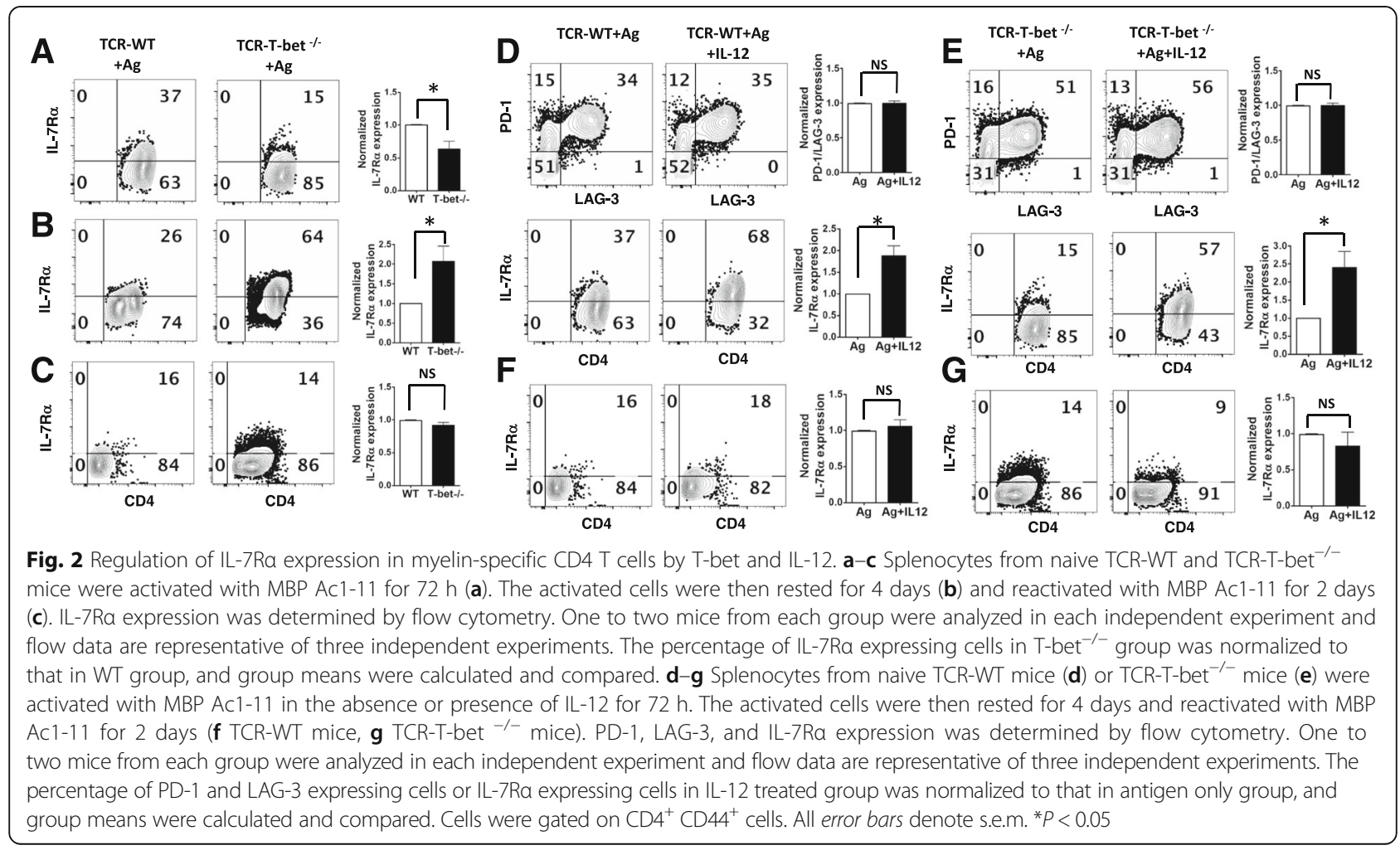


expression in myelin-specific CD4 T cells in a T-bet independent manner.

\section{Expression of inhibitory receptors and IL-7Ra in myelin-specific Th17 cells}

Previous studies have shown that myelin-specific Th17 cells are highly encephalitogenic in EAE, in addition to Th1 cells. We and others have demonstrated that Th17 cells differentiated with IL- 6 in the absence of Th1 and Th2 signaling are highly encephalitogenic, while Th17 cells differentiated with IL- 6 and TGF $\beta 1$ are not encephalitogenic following adoptive transfer $[6,34,35]$. Therefore, we analyzed the expression of PD-1 and IL-17R $\alpha$ on these two Th17 populations with distinct encephalitogenicity. Splenocytes from naïve TCR transgenic mice were activated with MBP Ac1-11 (Th neutral), MBP Ac1-11 plus IL-6 (encephalitogenic Th17) or MBP Ac1-11 plus IL-6, and TGF $\beta 1$ (non-encephalitogenic Th17) for 3 days. The encephalitogenic Th17 cells differentiated with IL-6 have a significantly higher IL$7 \mathrm{R} \alpha$ expressing population (Fig. 3a lower panels and c) and a significantly lower PD-1 expressing population (Fig. 3a upper panels and b) compared to nonencephalitogenic Th17 cells differentiated with IL- 6 and TGF $\beta 1$, suggesting that in addition to IL-12, IL-6 promotes IL-7R $\alpha$ expression and suppresses PD-1 expression in myelin-specific Th17 cells. Thus, IL- 6 appears to skew the IL-7R $\alpha / \mathrm{PD}-1$ balance towards IL-7R $\alpha$, favoring
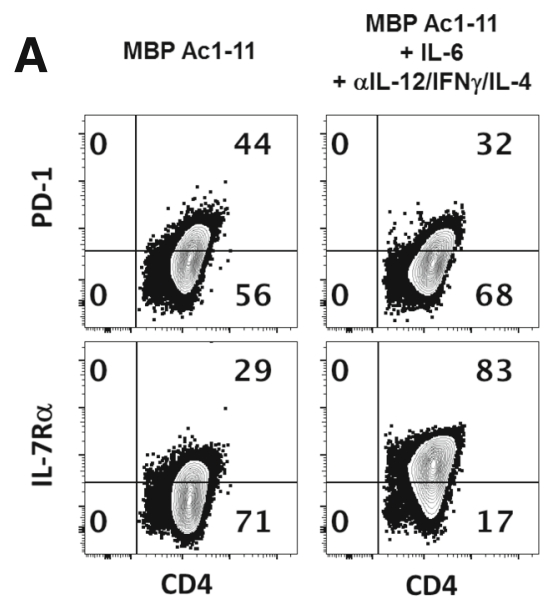

MBP Ac1-11
+ IL-6 + TGF $\beta$
$+\alpha$ IL-12/IFN $\gamma / I L-4$
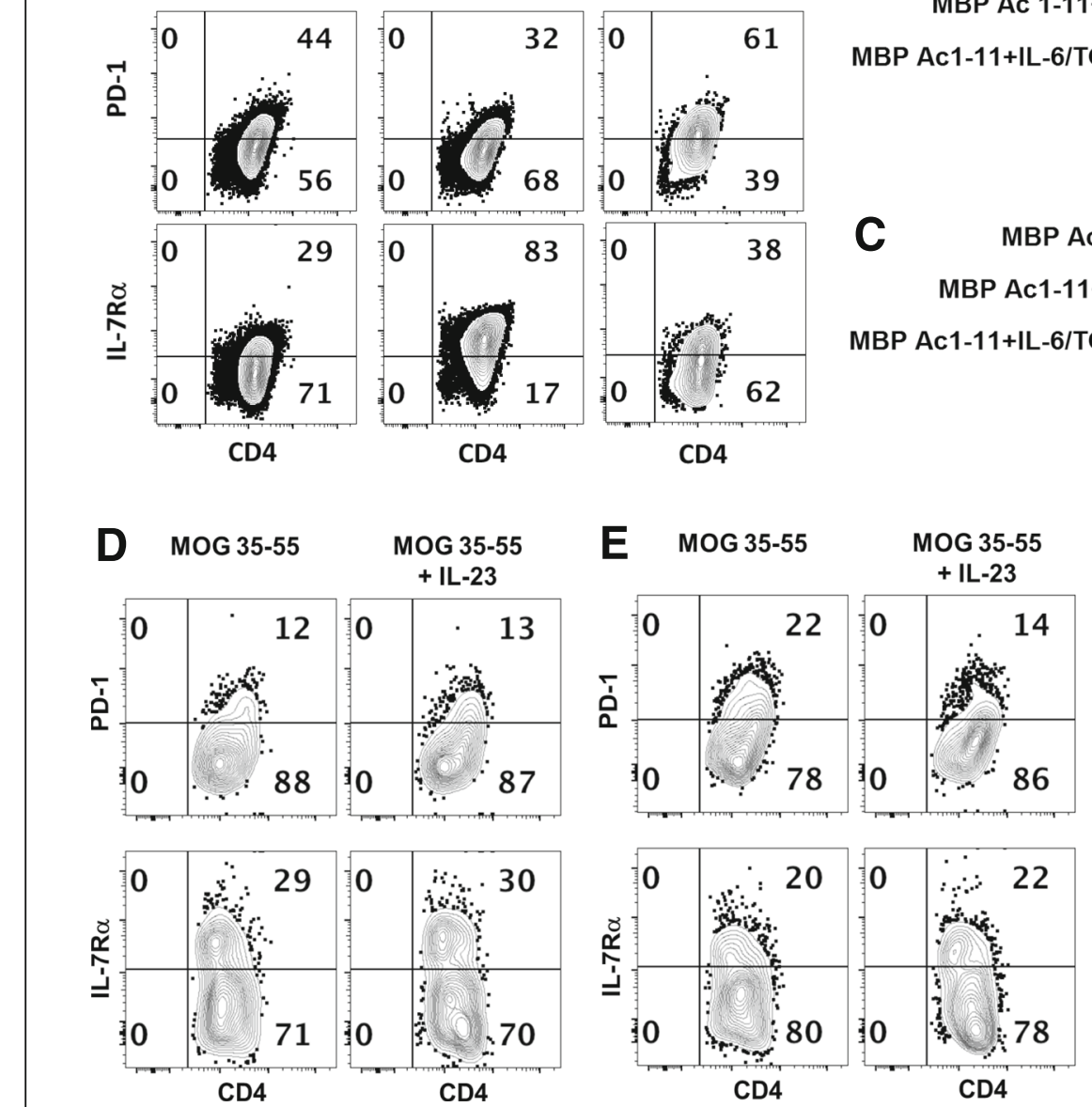
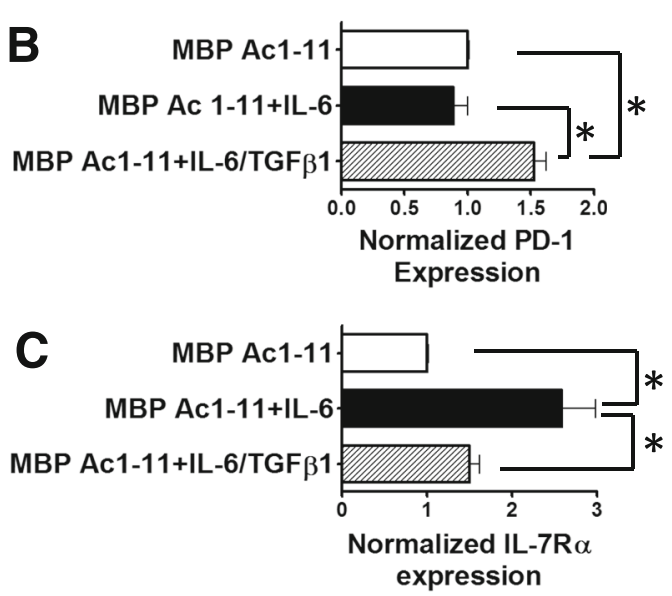

expression

Fig. 3 The expression of PD-1 and IL-7Ra in myelin-specific Th17 cells. a-c Splenocytes from naïve TCR-WT mice were activated with MBP Ac1-11 with different combination of cytokines for 3 days. PD-1 and IL-7Ra expression was determined by flow cytometry. The percentage of PD-1 (b) or IL-7Ra (c) expressing cells in MBP Ac1-11 plus IL-6 group or MBP Ac1-11 plus IL-6/TGF $\beta$ group was normalized to that in MBP Ac1-11 group. Group means were calculated and compared. Cells were gated on CD4 ${ }^{+} \mathrm{CD} 44^{+}$cells, and flow data are representative of three independent experiments. $\mathbf{d}-\mathbf{f}$ Draining LN cells from immunized WT/B6 (d) or T-bet ${ }^{-/-}$/B6 mice (e) were activated with MOG 35-55 or MOG 35-55 plus IL-23 for 3 days. PD-1 and IL-7Ra expression was determined by flow cytometry. IL-17 in supernatant was determined by ELISA (f). One to three mice from each group were analyzed in each independent experiment and flow data are representative of three independent experiments. All error bars denote s.e.m. ${ }^{*} P<0.05$ 
enhanced effector function of encephalitogenic Th17 cells. In contrast, the combination of IL-6 and TGF $\beta 1$ led to enhanced PD-1 expression (Fig. 3a-b) and skewed IL-7R $\alpha /$ PD-1 balance towards PD-1, which may contribute to the lack of encephalitogenicity of TGF $\beta /$ IL- 6 induced Th17 cells. Together, these data indicate that IL- 6 is also a major regulator of IL-7R $\beta / P D-1$ balance in myelin-specific CD4 T cells.

Although IL-6 is the key cytokine inducing the differentiation of encephalitogenic Th17 cells, IL-23 is important for the maintenance of encephalitogenic myelin-specific Th17 cells in EAE development $[5,36]$; however, IL-23 does not exert its function on naïve CD4 T cells, which do not express IL-23R at a significant level. Therefore, we analyzed the effects of IL-23 on IL-7R $\alpha / P D-1$ balance in effector myelin-specific CD4 $\mathrm{T}$ cells from EAE mice. Draining LN cells from MOG-immunized WT/B6 or Tbet $^{-1-} / \mathrm{B} 6$ mice were activated with MOG 35-55 in the presence or absence of IL-23. Although it increased IL-17 production significantly (Fig. 3f), the addition of IL-23 does not alter the expression of PD-1 or IL-7R $\alpha$ in activated WT (Fig. 3d) or $\mathrm{T}^{-}$bet $^{-1-} \mathrm{CD} 4 \mathrm{~T}$ effector cells (Fig. 3e); suggesting that IL-23 is not major regulator of IL-7R $\alpha /$ PD-1 balance in myelin-specific CD4 T cells.

To further confirm the effects of IL-23 on IL-7R $\alpha / \mathrm{PD}-1$ balance, the splenocytes from myelin-specific TCR transgenic mice that developed spontaneous EAE were activated in vitro with MBP Ac1-11, MBP Ac1-11 plus IL-12, or MBP Ac1-11 plus IL-23 for 3 days. As expected, the addition of IL-23 led to a significant increase of IL-17 production, while IL-12 led to a significant increase of IFNY secretion (Fig. 4a). However, IL-23 did not affect the expression of inhibitory receptors (PD-1 or LAG-3) (Fig. 4b upper panels) or IL-7R $\alpha$ (Fig. 4b lower panels) in effector/ memory CD4 T cells after antigen stimulation, while IL-12 significantly enhanced IL-7R $\alpha$ expression and suppressed LAG-3 expression in myelin-specific CD4 $\mathrm{T}$ effector/ memory cells from spontaneous EAE mice (Fig. 4b).

After resting and a 2nd round of stimulation, the cells activated with MBP Ac1-11 only during 1st round stimulation produced large amounts of IFN $\gamma$ and IL-17 during secondary stimulation regardless of the addition of IL-12 or IL-23 during 2nd round stimulation (Additional file 1: Figure S1A). However, the cells activated with IL-12 during 1st round stimulation produced high levels of IFNy but lower levels of IL-17. Interestingly, the cells activated with IL-23 during the 1st round of stimulation produced large amounts of IFNy and IL17 , regardless of the addition of IL-12 or IL-23 during secondary stimulation (Additional file 1: Figure S1A), confirming the plasticity of the cytokine phenotype of Th17 cells. Flow cytometric data showed that the addition of IL-23 during the 2nd round of stimulation does not alter the expression of inhibitory receptors in all three groups (Additional file 1: Figure S1b-d). Although it does not alter the expression of IL-7R $\alpha$ or inhibitory receptors (PD-1, LAG-3), IL-23 treated effector/memory cells appear to survive better after resting and 2nd round stimulation. After 2nd round stimulation with MBP Ac1-11, the cells cultured with MBP Ac1-11 plus IL-23 during the 1st round of stimulation had a significantly higher $\mathrm{CD}_{4} 4^{+}$population compared to the cells cultured with MBP Ac1-11 or MBP Ac1-11 plus IL12 during 1st round stimulation (Fig. 4c), suggesting that IL-23 promotes memory responses while IL-12 leads to terminal differentiation with poor memory potential. Taking together, our data suggest that IL-6 and IL-23, although both are important for Th17 development, have distinct regulation of IL-7R $\alpha / \mathrm{PD}-1$ balance.

\section{IL-7 signaling inhibits PD-1 expression in myelin-specific CD4 T cells}

To determine whether IL-7 signaling regulates PD-1 expression in myelin-specific CD4 T cells, splenocytes from naïve TCR V $\beta 8.2$ transgenic mice, which have a high frequency of myelin-specific $T$ cells and allow for evaluation of a myelin-specific response in a diverse $T$ cell population, were activated with MBP Ac1-11 in the presence or absence of different concentrations of IL-7 for 6 days. As shown in Fig. 5a-b, the addition of IL-7 inhibits PD-1 expression in myelin-specific CD4 $\mathrm{T}$ cells in a dose dependent manner, with a significant suppression at the concentrations of $1 \mathrm{ng} / \mathrm{ml}, 10 \mathrm{ng} / \mathrm{ml}$, and $50 \mathrm{ng} / \mathrm{ml}$, suggesting that IL-7 signaling inhibits PD-1 expression in myelin-specific CD4 T cells. Furthermore, to determine whether manipulating the IL-7R $\alpha / \mathrm{PD}-1$ balance alters $\mathrm{T}$ cell encephalitogenicity of myelin-specific CD4 T cells, splenocytes from naïve TCR $\alpha \beta$ transgenic mice were activated with MBP Ac1-11, MBP Ac1-11 plus IL-7, or MBP Ac1-11 plus $\alpha$ IL-7R $\alpha$ for 3 days, followed by adoptive transfer into naïve B10.PL recipient mice. Our data showed that blocking IL-7 signaling in myelin-specific CD4 $\mathrm{T}$ cells by $\alpha \mathrm{IL}-7 \mathrm{R} \alpha$ significantly delays EAE onset and reduces disease severity (Fig. 5c and Table 1), although it does not alter IL-17 or IFNY production significantly (Fig. 5d).

\section{Discussion}

IFN $\gamma$ producing Th1 cells and IL-17 producing Th17 cells are highly encephalitogenic in the EAE model of MS, although they have distinct signature cytokine profiles, prompting us to hypothesize that molecules other than the signature cytokines regulate the effector function and contribute to the encephalitogenicity of both myelin-specific Th1 and Th17 cells. IL-7R $\alpha$ and the inhibitory receptor PD- 1 are essential parts of the cell-intrinsic immunoregulatory program regulating $\mathrm{CD} 4 \mathrm{~T}$ effector function. Although both 

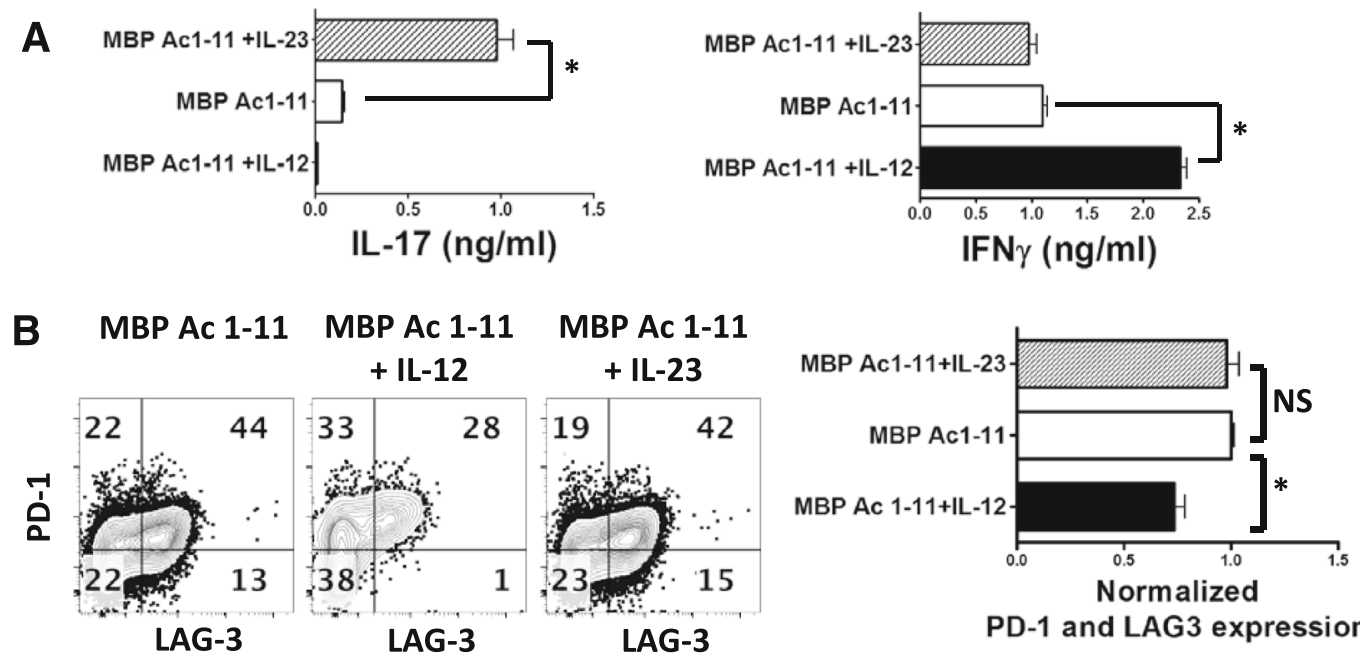

PD-1 and LAG3 expression
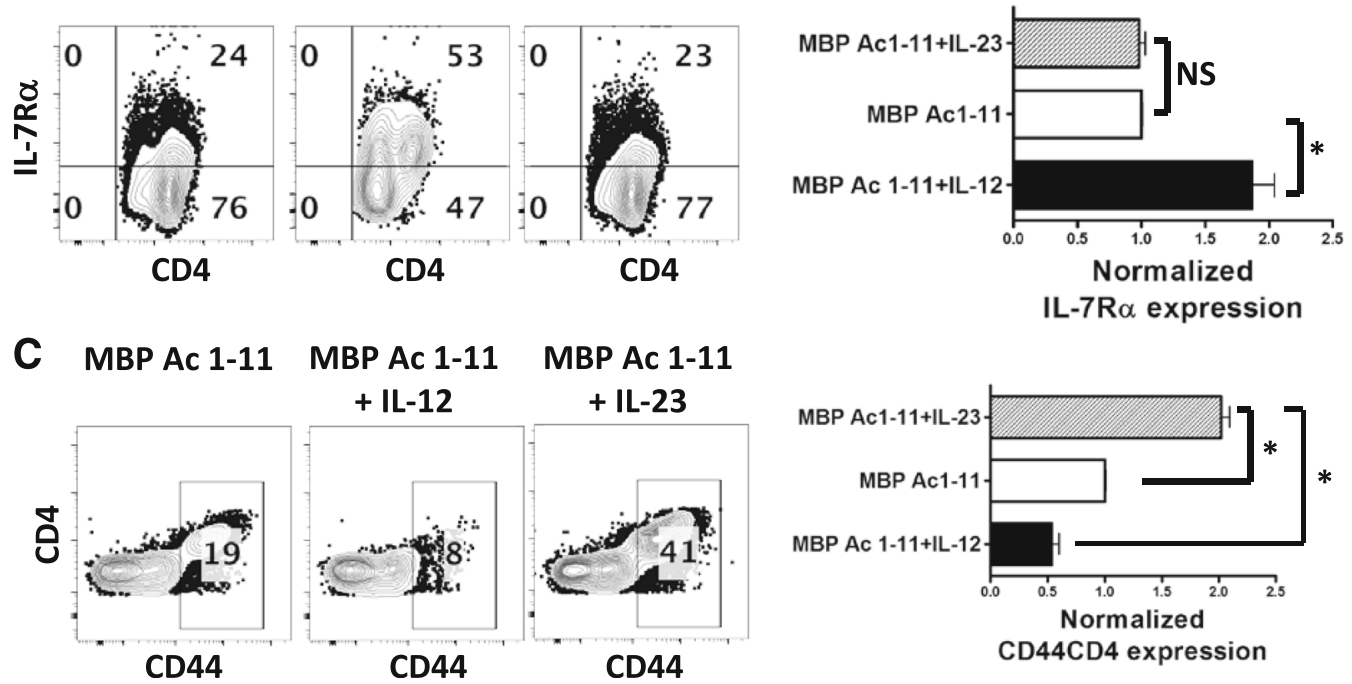

MBP AC 1-11

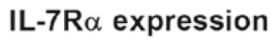

Fig. 4 IL-23 expands myelin-specific CD4 T effector/memory cells from spontaneous EAE mice but does not alter PD-1/IL-7Ra balance. a-b Splenocytes from TCR-WT mice who developed spontaneous EAE were activated with MBP Ac1-11, MBP Ac1-11 plus IL-12, or MBP Ac1-11 plus IL-23 for 72 h. a IL-17 and IFNy in supernatant were determined by ELISA. b PD-1, LAG-3, and IL-7Ra expression was determined by flow cytometry. Cells were gated on $\mathrm{CD}_{4}^{+} \mathrm{CD}_{4} 4^{+}$cells and flow data are representative of three independent experiments. The percentage of PD- $1^{+} \mathrm{LAG}-3^{+} \mathrm{CD} 4^{+} \mathrm{T}$ cells or IL-7Ra expressing cells in MBP Ac1-11 plus IL-23 group or MBP Ac1-11 plus IL-12 group was normalized to that in MBP Ac1-11 group. Group means were calculated and compared. c Splenocytes from TCR-WT mice who developed spontaneous EAE were activated with MBP Ac1-11, MBP Ac1-11 plus IL-12, or IL-23 for $72 \mathrm{~h}$. The cells were then rested for 4 days and restimulated with MBP Ac1-11 for 2 days. CD44 expression was determined by flow cytometry. Flow data are representative of three independent experiments. The percentage of CD $44^{+} C D 4^{+} T$ cells in MBP Ac1-11 plus IL-23 group or MBP Ac1-11 plus IL-12 group was normalized to that in MBP Ac1-11 group. Group means were calculated and compared. All error bars denote s.e.m. ${ }^{*} P<0.05$

IL-7R $\alpha$ and PD-1 have been implicated in the pathogenesis of MS/EAE, the factors regulating their expression in myelin-specific CD4 $\mathrm{T}$ cells during EAE development are not well-elucidated. This study aims to determine if the key factors regulating $\mathrm{T}$ cell encephalitogenicity of myelin-specific Th1 and Th17 cells, including transcription factor T-bet and cytokines (IL12, IL-6, and IL-23), may exert their function through regulating IL-7R $\alpha / \mathrm{PD}-1$ balance in myelin-specific CD4 $\mathrm{T}$ cells during EAE development.
T-bet is the key transcription factor regulating the differentiation of Th1 cells. T-bet deficient mice were originally shown to be resistant to EAE induction by active immunization [31], but later studies showed that T-bet deficient mice are still susceptible to EAE induction and T-bet is essential for Th1-mediated, but not Th17mediated, CNS autoimmune disease [27, 37]. Although these results from genetically engineered mice appear to contradict each other, other studies support an important role of T-bet in EAE [28-30] and MS [38, 39] as a 


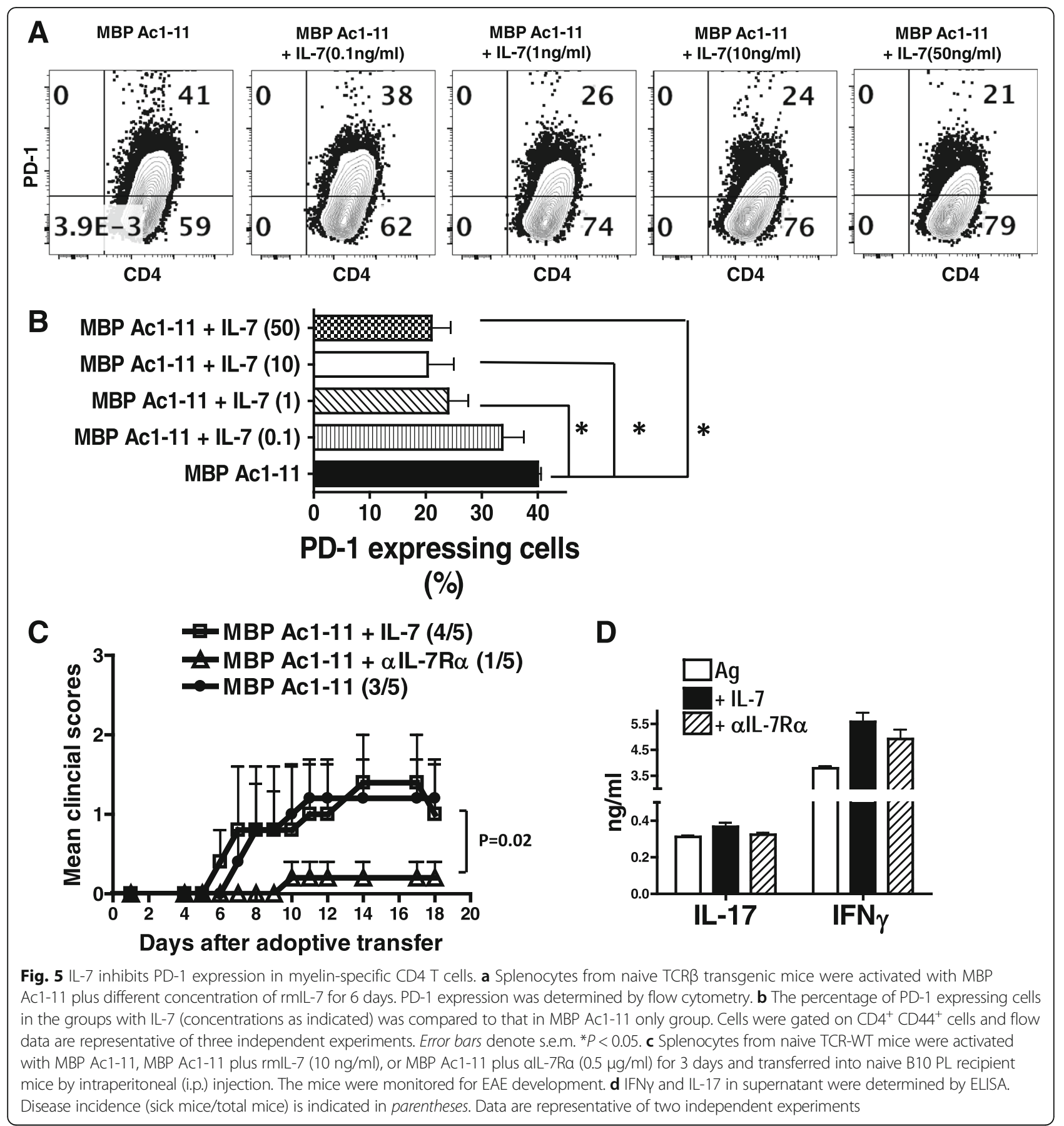

Table 1 Blockade of IL-7 receptor signaling decreases T cell encephalitogenicity

\begin{tabular}{llllll}
\hline Conditions & Number of mice & Incidence of EAE (\%) & $\begin{array}{l}\text { Mean day of onset } \\
\text { of EAE mice }\end{array}$ & $\begin{array}{l}\text { Mean peak clinical } \\
\text { score of all mice }\end{array}$ & $\begin{array}{l}\text { Mean peak clinical } \\
\text { score of EAE mice }\end{array}$ \\
\hline Ag only & 11 & $7 / 11(64 \%)$ & 9 & $1.64^{\mathrm{a}}$ & 2.57 \\
$\mathrm{Ag}+\mathrm{IL}-7$ & 11 & $9 / 11(82 \%)$ & 10 & $2.18^{\mathrm{b}}$ & 2.67 \\
$\mathrm{Ag}+\mathrm{alL}-7 \mathrm{Ra}$ & 12 & $4 / 12(33 \%)$ & 11.5 & $0.58^{\mathrm{a}, \mathrm{b}}$ & 1.75 \\
\hline
\end{tabular}

${ }^{a}$ Mean peak clinical score of all mice: Ag + all-7Ra vs Ag only $(P<0.05)$

${ }^{b}$ Mean peak clinical score of all mice: Ag + all-7Ra vs Ag + IL-7 $(P<0.05)$ 
potential therapeutic target. Our data showed that T-bet is a major regulator of IL-7R $\alpha / \mathrm{PD}-1$ balance in myelinspecific CD4 $\mathrm{T}$ effector/memory cells differentiated in vitro and during EAE development in vivo. T-bet suppresses the expression of inhibitory receptors, which is similar to what was observed in CD8 $\mathrm{T}$ cells during chronic infection [32]. Meanwhile, T-bet enhances IL$7 \mathrm{R} \alpha$ expression in myelin-specific CD4 T cells. IL-7R $\alpha$ expression in myelin-specific CD4 T cells is dysregulated when T-bet is deficient. Upon antigen encounter, myelin-specific CD4 T cells from WT mice upregulate IL-7R $\alpha$, but myelin-specific CD4 $\mathrm{T}$ cells from T-bet deficient mice fail to upregulate IL-7R $\alpha$ after primary stimulation. After CD4 T cells are rested for 4 days, IL$7 \mathrm{R} \alpha$ expression is downregulated in myelin-specific CD4 $\mathrm{T}$ cells from WT mice but is upregulated in T-bet deficient myelin-specific CD4 $\mathrm{T}$ cells. After antigen restimulation, IL-7R $\alpha$ expression is similar between two groups while T-bet deficient myelin-specific CD4 $\mathrm{T}$ cells have notably higher $\mathrm{PD}-1$ expression. Altogether, our data suggest that T-bet is a key transcription factor regulating IL-7R $\alpha / \mathrm{PD}-1$ balance in myelin-specific CD4 T cells.

After the identification of Th17 cells as another encephalitogenic $\mathrm{CD} 4 \mathrm{~T}$ helper population in addition to Th1 cells in EAE, the search for the potential therapeutic targets that convey the encephalitogenicity to myelin-specific CD4 $\mathrm{T}$ cells becomes even more complicated. Although IFN $\gamma$ producing Th1 and IL-17 producing Th17 cells are both encephalitogenic, they have distinct cytokine profile, which raises the question whether encephalitogenic CD4 $\mathrm{T}$ cells exert their function mainly through the production of signature cytokines. Both IFN $\gamma$ and IL-17 deficient mice are still susceptible to EAE induction $[7,8]$. On a related note, we previously showed that myelin-specific Th17 cells induced with IL- 6 in the absence of Th1 and Th2 signaling are highly encephalitogenic following adoptive transfer while myelin-specific Th17 cells induced with the combination of TGF $\beta$ and IL-6, although producing large amounts of IL-17, are not encephalitogenic $[6,40]$. These data clearly argue that there are molecules other than the signature cytokines responsible for the encephalitogenicity of myelin-specific CD4 T cells, although the detailed mechanisms are still unclear. IL-12 and IL- 6 are two critical cytokines for the differentiation of encephalitogenic Th1 and Th17 differentiation, respectively. Our data showed that IL-12 and IL- 6 have similar effects in regulating IL-7R $\alpha / \mathrm{PD}-1$ balance by skewing the balance towards IL-7R $\alpha$ in both Th1 and Th17 cells. On the other hand, TGF $\beta 1 / \mathrm{IL}-6$ induced non-encephalitogenic Th17 cells have an IL-7R $\alpha / \mathrm{PD}-1$ balance skewed towards PD-1. These data suggest that IL-7R $\alpha / \mathrm{PD}-1$ balance is a common mechanism shared by both Th1 and encephalitogenic Th17 cells to regulate effector function. Therefore, it may be possible to target both Th1 and Th17 cells by manipulating IL-7R $\alpha /$ PD-1 balance.

Targeting PD-1/PD-L1 pathway for therapeutic purposes has been explored in cancer and chronic viral infection [41]. Contrary to autoimmunity, tumor cells upregulate PD-L1 which binds its receptors (PD-1, etc.) on T effector cells, thus paralyzing $\mathrm{T}$ cells, suppressing tumor immunity, and allowing the tumor to evade immune attack. Therefore, anti-PD therapy has been developed and tested in clinical trials and these trials have shown remarkable success for treating human cancer, especially solid tumors. The FDA recently approved two PD-1 monoclonal antibodies to treat human cancers. Additionally, multiple monoclonal antibodies to either PD-1 or PD-L1 are under active development in clinical trials [42, 43]. Similarly, in the scenario of chronic viral infection, after prolonged exposure to antigen and inflammation, exhausted $\mathrm{T}$ cells express high levels of PD-1 and other inhibitory receptors, resulting loss of robust effector function [9]. Preclinical data have shown that targeting PD-1/PD-L1 pathway can improve $\mathrm{T}$ cell responses and viral clearance [10,42].

In the context of autoimmunity, our data demonstrate that several major determinants of $\mathrm{T}$ cell encephalitogenicity, including T-bet, IL-12, and IL-6, skew IL-7R $\alpha /$ PD-1 balance towards IL-7R $\alpha$, favoring an encephalitogenic phenotype of myelin-specific CD4 T cells with enhanced effector function. Our data show that IL-7 signaling inhibits PD-1 expression in myelin-specific CD4 T cells and blockade of IL-7R signaling on myelin-specific CD4 T cells significantly decreased the encephalitogenic potential of those cells. Therefore, skewing IL-7R $\alpha / \mathrm{PD}-1$ balance towards PD-1 by either stimulating PD-1/PD-L1 pathway or suppressing IL-7R $\alpha$ signaling may have therapeutic potential for the treatment of autoimmune diseases, including MS.

\section{Conclusions}

In this study, we characterized the factors regulating IL7R $\alpha / \mathrm{PD}-1$ balance in myelin-specific CD4 $\mathrm{T}$ effector/ memory cells during EAE development. We have shown that T-bet is a major transcription factor regulating IL$7 R \alpha / P D-1$ balance in myelin-specific CD4 T cells, and there is a positive correlation between several major determinants promoting $\mathrm{T}$ cell encephalitogenicity (T-bet, IL-6, IL-12) and an IL-7R $\alpha / P D-1$ balance skewed towards IL$7 R \alpha$, suggesting that those major determinants critical to $\mathrm{T}$ cell encephalitogenicity may exert their function through regulation of IL-7R $\alpha / \mathrm{PD}-1$ balance. Additionally, IL-7 signaling inhibits PD-1 expression in myelin-specific CD4 T cells and blocking IL-7 signaling suppresses T cell encephalitogenicity. Therefore, interference with inhibitory pathways and IL-7R $\alpha$ expression may suppress the encephalitogenic potential of myelin-specific CD4 T cells and have therapeutic benefits for MS patients. 


\section{Additional file}

Additional file 1: Figure S1. Splenocytes from TCR-WT mice who developed spontaneous EAE were activated with MBP Ac1-11, MBP Ac1-11 plus IL-12, or MBP Ac1-11 plus IL-23 for $72 \mathrm{~h}$. The cells were then rested for 4 days and restimulated with MBP Ac1-11, MBP Ac1-11 plus IL-12, or MBP Ac1-11 plus IL-23 for 2 days. (A) IL-17 and IFNy in supernatant after the 2 nd round of stimulation were determined by ELISA. (B-D) PD-1, LAG-3, or IL-7Ra expression in myelin-specific CD4 T cells after the 2nd round of stimulation were determined by flow cytometry. The cells were gated on $\mathrm{CD}_{4} 4^{+} \mathrm{CD} 4^{+} \mathrm{T}$ effector cells. Data are representative of three independent experiments. (PDF 308 kb)

\section{Abbreviations}

CNS: Central nervous system; EAE: Experimental autoimmune encephalomyelitis; MBP: Myelin basic protein; MOG: Myelin oligodendrocyte glycoprotein; MS: Multiple sclerosis

\section{Acknowledgements}

Not applicable.

\section{Funding}

This study was supported by grants from the National MS Society to $Y Y$ (PP2080) and NIH to YY (1R01NS088437-01A1) and AEL-R (RO1 NS 067441). PKN-G was supported by the NIH Postbacculaureate Research Education Program (PREP), grant R25 GM089571.

\section{Availability of data and materials}

All raw data used in this manuscript will be made available upon request.

\section{Authors' contributions}

YY designed research, analyzed the results, and wrote the paper. PKN-G, ELR, MCG, PWL, and SA performed the experiments. WP provided support of mouse studies. YL provided general support. AEL-R, MKR, and JZ helped with data discussion and manuscript review. All authors read and approved the final manuscript.

\section{Competing interests}

The authors declare that they have no competing interests with the contents in this paper

\section{Consent for publication}

Not applicable.

\section{Ethics approval and consent to participate}

All animal protocols were approved by the OSU Institutional Animal Care and Use Committee.

\section{Author details}

${ }^{1}$ Postbacculaureate Research Education Program, The Ohio State University, Columbus, OH, USA. ${ }^{2}$ Neuroscience program, College of Arts and Sciences, The Ohio State University, Columbus, $\mathrm{OH}$, USA. ${ }^{3}$ Department of Neurology, Wexner Medical Center, The Ohio State University, Columbus, OH, USA. ${ }^{4}$ Department of Microbial Infection and Immunity, Wexner Medical Center, The Ohio State University, Columbus, OH, USA. ${ }^{5}$ Molecular Cellular and Developmental Biology Graduate Program, The Ohio State University, Columbus, OH, USA. 'Department of Neuroscience, Wexner Medical Center, The Ohio State University, Columbus, OH, USA. Department of Neurology, Wexner Medical Center, Biomedical Research Tower, The Ohio State University, 460 W 12th Ave, Room 0604, Columbus, OH 43210, USA.

Received: 21 April 2016 Accepted: 24 November 2016 Published online: 03 December 2016

\section{References}

1. Frohman EM, Racke MK, Raine CS. Multiple sclerosis-the plaque and its pathogenesis. N Engl J Med. 2006;354:942-55.

2. Ando DG, Clayton J, Kono D, Urban JL, Sercarz EE. Encephalitogenic T cells in the B10.PL model of experimental allergic encephalomyelitis (EAE) are of the Th-1 lymphokine subtype. Cell Immunol. 1989;124:132-43.
3. Pettinelli CB, McFarlin DE. Adoptive transfer of experimental allergic encephalomyelitis in SJL/J mice after in vitro activation of lymph node cells by myelin basic protein: requirement for Lyt 1+ 2-T lymphocytes. J Immunol. 1981:127:1420-3.

4. Waldburger KE, Hastings RC, Schaub RG, Goldman SJ, Leonard JP. Adoptive transfer of experimental allergic encephalomyelitis after in vitro treatment with recombinant murine interleukin-12. Preferential expansion of interferon-gamma-producing cells and increased expression of macrophage-associated inducible nitric oxide synthase as immunomodulatory mechanisms. Am J Pathol. 1996;148:375-82.

5. Langrish $\mathrm{CL}$, Chen Y, Blumenschein WM, Mattson J, Basham B, Sedgwick JD, McClanahan T, Kastelein RA, Cua DJ. IL-23 drives a pathogenic T cell population that induces autoimmune inflammation. J Exp Med. 2005;201:233-40.

6. Yang Y, Weiner J, Liu Y, Smith AJ, Huss DJ, Winger R, Peng H, Cravens PD, Racke MK, Lovett-Racke AE. T-bet is essential for encephalitogenicity of both Th1 and Th17 cells. J Exp Med. 2009:206:1549-64.

7. Ferber IA, Brocke S, Taylor-Edwards C, Ridgway W, Dinisco C, Steinman L, Dalton D, Fathman CG. Mice with a disrupted IFN-gamma gene are susceptible to the induction of experimental autoimmune encephalomyelitis (EAE). J Immunol. 1996;156:5-7.

8. Haak S, Croxford AL, Kreymborg K, Heppner FL, Pouly S, Becher B, Waisman A. IL-17A and IL-17F do not contribute vitally to autoimmune neuro-inflammation in mice. J Clin Invest. 2009;119:61-9.

9. Wherry EJ. T cell exhaustion. Nat Immunol. 2011;131:492-9.

10. Pauken KE, Wherry EJ. Overcoming $T$ cell exhaustion in infection and cancer. Trends Immunol. 2015;36:265-76.

11. Barber DL, Wherry EJ, Masopust D, Zhu B, Allison JP, Sharpe AH, Freeman GJ, Ahmed R. Restoring function in exhausted CD8 T cells during chronic viral infection. Nature. 2006:439:682-7.

12. Iwai Y, Ishida M, Tanaka Y, Okazaki T, Honjo T, Minato N. Involvement of PD-L1 on tumor cells in the escape from host immune system and tumor immunotherapy by PD-L1 blockade. Proc Natl Acad Sci U S A. 2002;99:12293-7.

13. Hirano F, Kaneko K, Tamura H, Dong H, Wang S, Ichikawa M, Rietz C, Flies DB, Lau JS, Zhu G, Tamada K, Chen L. Blockade of B7-H1 and PD-1 by monoclonal antibodies potentiates cancer therapeutic immunity. Cancer Res. 2005;65:1089-96.

14. Lee LF, Logronio K, Tu GH, Zhai W, Ni I, Mei L, Dilley J, Yu J, Rajpal A, Brown C, Appah C, Chin SM, Han B, Affolter T, Lin JC. Anti-IL-7 receptor-alpha reverses established type 1 diabetes in nonobese diabetic mice by modulating effector T-cell function. Proc Natl Acad Sci U S A. 2012;109:12674-9.

15. Penaranda C, Kuswanto W, Hofmann J, Kenefeck R, Narendran P, Walker LS, Bluestone JA, Abbas AK, Dooms H. IL-7 receptor blockade reverses autoimmune diabetes by promoting inhibition of effector/memory T cells. Proc Natl Acad Sci U S A. 2012;109:12668-73.

16. Gregory SG, Schmidt S, Seth P, Oksenberg JR, Hart J, Prokop A, Caillier SJ, Ban M, Goris A, Barcellos LF, Lincoln R, McCauley JL, Sawcer SJ, Compston DA, Dubois B, Hauser SL, Garcia-Blanco MA, Pericak-Vance MA, Haines JL, G. Multiple Sclerosis Genetics. Interleukin 7 receptor alpha chain (IL7R) shows allelic and functional association with multiple sclerosis. Nat Genet. 2007:39:1083-91.

17. International Multiple Sclerosis Genetics, C, Hafler DA, Compston A, Sawcer S, Lander ES, Daly MJ, De Jager PL, de Bakker PI, Gabriel SB, Mirel DB, Ivinson AJ, Pericak-Vance MA, Gregory SG, Rioux JD, McCauley JL, Haines JL, Barcellos LF, Cree B, Oksenberg JR, Hauser SL. Risk alleles for multiple sclerosis identified by a genomewide study. N Engl J Med. 2007;357:851-62.

18. Lundmark F, Duvefelt K, lacobaeus E, Kockum I, Wallstrom E, Khademi M, Oturai A, Ryder LP, Saarela J, Harbo HF, Celius EG, Salter H, Olsson T, Hillert J. Variation in interleukin 7 receptor alpha chain (IL7R) influences risk of multiple sclerosis. Nat Genet. 2007:39:1108-13.

19. Lee LF, Axtell R, Tu GH, Logronio K, Dilley J, Yu J, Rickert M, Han B, Evering W, Walker MG, Shi J, de Jong BA, Killestein J, Polman CH, Steinman L, Lin JC. IL-7 promotes T (H) 1 development and serum IL-7 predicts clinical response to interferon-beta in multiple sclerosis. Sci Transl Med. 2011;3:93ra68

20. Walline CC, Kanakasabai S, Bright JJ. IL-7Ra confers susceptibility to experimental autoimmune encephalomyelitis. Genes Immun. 2011;12:1-14.

21. Ashbaugh JJ, Brambilla R, Karmally SA, Cabello C, Malek TR, Bethea JR. IL7Ra contributes to experimental autoimmune encephalomyelitis through altered $T$ cell responses and nonhematopoietic cell lineages. J Immunol. 2013:190:4525-34 
22. Kroner A, Schwab N, Ip CW, Ortler S, Gobel K, Nave KA, Maurer M, Martini R, Wiendl $\mathrm{H}$. Accelerated course of experimental autoimmune encephalomyelitis in PD-1-deficient central nervous system myelin mutants. Am J Pathol. 2009; 174:2290-9.

23. Salama AD, Chitnis T, Imitola J, Ansari MJ, Akiba H, Tushima F, Azuma M, Yagita $H$, Sayegh MH, Khoury SJ. Critical role of the programmed death-1 (PD-1) pathway in regulation of experimental autoimmune encephalomyelitis. J Exp Med. 2003;198:71-8.

24. Kroner A, Mehling M, Hemmer B, Rieckmann P, Toyka KV, Maurer M, Wiendl H. A PD-1 polymorphism is associated with disease progression in multiple sclerosis. Ann Neurol. 2005:58:50-7.

25. Goverman J, Woods A, Larson L, Weiner LP, Hood L, Zaller DM. Transgenic mice that express a myelin basic protein-specific $T$ cell receptor develop spontaneous autoimmunity. Cell. 1993;72:551-60.

26. Szabo SJ, Kim ST, Costa GL, Zhang X, Fathman CG, Glimcher LH. A novel transcription factor, T-bet, directs Th1 lineage commitment. Cell. 2000;100:655-69.

27. O'Connor RA, Cambrook H, Huettner K, Anderton SM. T-bet is essential for Th1-mediated, but not Th17-mediated, CNS autoimmune disease. Eur J Immunol. 2013;43:2818-23.

28. Nath N, Prasad R, Giri S, Singh AK, Singh I. T-bet is essential for the progression of experimental autoimmune encephalomyelitis. Immunology. 2006;118:384-91.

29. Lovett-Racke AE, Rocchini AE, Choy J, Northrop SC, Hussain RZ, Ratts RB, Sikder D, Racke MK. Silencing T-bet defines a critical role in the differentiation of autoreactive T lymphocytes. Immunity. 2004;21: 719-31.

30. Gocke AR, Cravens PD, Ben LH, Hussain RZ, Northrop SC, Racke MK, Lovett-Racke AE. T-bet regulates the fate of Th1 and Th17 lymphocytes in autoimmunity. J Immunol. 2007;178:1341-8.

31. Bettelli E, Sullivan B, Szabo SJ, Sobel RA, Glimcher LH, Kuchroo VK. Loss of T-bet, but not STAT1, prevents the development of experimental autoimmune encephalomyelitis. J Exp Med. 2004;200:79-87.

32. Kao C, Oestreich KJ, Paley MA, Crawford A, Angelosanto JM, Ali MA, Intlekofer AM, Boss JM, Reiner SL, Weinmann AS, Wherry EJ. Transcription factor T-bet represses expression of the inhibitory receptor PD-1 and sustains virus-specific CD8+ T cell responses during chronic infection. Nat Immunol. 2011;12:663-71.

33. Yang $Y$, Winger RC, Lee PW, Nuro-Gyina PK, Minc A, Larson $M$, Liu Y, Pei W, Rieser E, Racke MK, Lovett-Racke AE. Impact of suppressing retinoic acid-related orphan receptor gamma $t(R O R) \gamma t$ in ameliorating central nervous system autoimmunity. Clin Exp Immunol. 2015;179:108-18.

34. Ghoreschi K, Laurence A, Yang XP, Tato CM, McGeachy MJ, Konkel JE, Ramos HL, Wei L, Davidson TS, Bouladoux N, Grainger JR, Chen Q, Kanno Y, Watford WT, Sun HW, Eberl G, Shevach EM, Belkaid Y, Cua DJ, Chen W, O'Shea JJ. Generation of pathogenic T (H) 17 cells in the absence of TGF- $\beta$ signalling. Nature. 2010;467:967-71.

35. Das J, Ren G, Zhang L, Roberts Al, Zhao X, Bothwell AL, Van Kaer L, Shi $Y$, Das G. Transforming growth factor beta is dispensable for the molecular orchestration of Th17 cell differentiation. J Exp Med. 2009; 206:2407-16.

36. Cua DJ, Sherlock J, Chen Y, Murphy CA, Joyce B, Seymour B, Lucian L, To W, Kwan S, Churakova T, Zurawski S, Wiekowski M, Lira SA, Gorman D, Kastelein RA, Sedgwick JD. Interleukin-23 rather than interleukin-12 is the critical cytokine for autoimmune inflammation of the brain. Nature. 2003;421:744-8.

37. Grifka-Walk HM, Lalor SJ, Segal BM. Highly polarized Th17 cells induce EAE via a T-bet independent mechanism. Eur J Immunol. 2013;43:2824-31.

38. Frisullo G, Angelucci F, Caggiula M, Nociti V, lorio R, Patanella AK, Sancricca C, Mirabella M, Tonali PA, Batocchi AP. pSTAT1, pSTAT3, and T-bet expression in peripheral blood mononuclear cells from relapsing-remitting multiple sclerosis patients correlates with disease activity. J Neurosci Res. 2006;84:1027-36

39. Frisullo G, Nociti V, lorio R, Katia Patanella A, Bianco A, Caggiula M, Sancricca C, Tonali PA, Mirabella M, Batocchi AP. Glucocorticoid treatment reduces T-bet and PSTAT1 expression in mononuclear cells from relapsing remitting multiple sclerosis patients. Clin Immunol. 2007;124:284-93.

40. Lee PW, Yang Y, Racke MK, Lovett-Racke AE. Analysis of TGF-beta1 and TGF-beta3 as regulators of encephalitogenic Th17 cells: implications for multiple sclerosis. Brain Behav Immun. 2015;46:44-9.
41. McDermott DF, Atkins MB. PD-1 as a potential target in cancer therapy. Cancer Med. 2013;2:662-73.

42. Chinai JM, Janakiram M, Chen F, Chen W, Kaplan M, Zang X. New immunotherapies targeting the PD-1 pathway. Trends Pharmacol Sci. 2015;36:587-95.

43. Chen L, Han X. Anti-PD-1/PD-L1 therapy of human cancer: past, present, and future. J Clin Invest. 2015;125:3384-91.

\section{Submit your next manuscript to BioMed Central and we will help you at every step:}

- We accept pre-submission inquiries

- Our selector tool helps you to find the most relevant journal

- We provide round the clock customer support

- Convenient online submission

- Thorough peer review

- Inclusion in PubMed and all major indexing services

- Maximum visibility for your research

Submit your manuscript at www.biomedcentral.com/submit 